\title{
Clinical perspectives in congenital adrenal hyperplasia due to $3 \beta$ - hydroxysteroid dehydrogenase type 2 deficiency
}

\author{
Abdullah M. Al Alawi, ${ }^{1,2}$ Anna Nordenström ${ }^{3,4} \cdot$ Henrik Falhammar $\mathbb{D}^{2,5,6,7}$ \\ Received: 24 November 2018 / Accepted: 27 December 2018 / Published online: 4 February 2019 \\ (C) The Author(s) 2019
}

\begin{abstract}

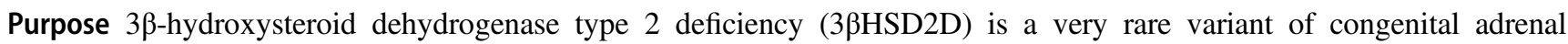
hyperplasia $(\mathrm{CAH})$ causing less than $0.5 \%$ of all $\mathrm{CAH}$. The aim was to review the literature.

Methods PubMed was searched for relevant articles.

Results $3 \beta \mathrm{HSD} 2 \mathrm{D}$ is caused by $H S D 3 B 2$ gene mutations and characterized by impaired steroid synthesis in the gonads and the adrenal glands and subsequent increased dehydroepiandrosterone (DHEA) concentrations. The main hormonal changes observed in patients with $3 \beta \mathrm{HSD} 2 \mathrm{D}$ are elevated ratios of the $\Delta 5$-steroids over $\Delta 4$-steroids but molecular genetic testing is recommended to confirm the diagnosis. Several deleterious mutations in the HSD3B2 gene have been associated with saltwasting (SW) crisis in the neonatal period, while missense mutations have been associated with a non-SW phenotype. Boys may have ambiguous genitalia, whereas girls present with mild or no virilization at birth. The existence of non-classic $3 \beta \mathrm{HSD} 2 \mathrm{D}$ is controversial. In an acute SW crisis, the treatment includes prompt rehydration, correction of hypoglycemia, and parenteral hydrocortisone. Similar to other forms of $\mathrm{CAH}$, glucocorticoid and mineralocorticoid replacement is needed for long-term management. In addition, sex hormone replacement therapy may be required if normal progress through puberty is failing. Little is known regarding possible negative long-term consequences of $3 \beta \mathrm{HSD} 2 \mathrm{D}$ and its treatments, e.g., fertility, final height, osteoporosis and fractures, adrenal and testicular tumor risk, and mortality.

Conclusion Knowledge is mainly based on case reports but many long-term outcomes could be presumed to be similar to other types of $\mathrm{CAH}$, mainly 21-hydroxylase deficiency, although in 3 $\beta$ HSD2D it seems to be more difficult to suppress the androgens.
\end{abstract}

Keywords $3 \beta \mathrm{HSD} 2 \mathrm{D} \cdot$ Diagnosis $\cdot$ Management $\cdot$ Outcomes $\cdot$ Mutations $\cdot$ Dehydroepiandrosterone

\section{Introduction}

Congenital adrenal hyperplasia $(\mathrm{CAH})$ is a group of disorders caused by deficiency of one of five enzymes that are responsible for making cortisol from cholesterol in the adrenal glands [1-3]. 21-hydroxylase deficiency (21OHD) is the most common disorder causing CAH (95-99\%) followed by 11-beta-hydroxylase deficiency (11OHD) [2, 4-7].

$3 \beta$-hydroxysteroid dehydrogenase type 2 deficiency (3ßHSD2D) $[8,9]$, is a very rare type of $\mathrm{CAH}$ affecting $<0.5 \%$ of all CAH $[4,5]$, and with $<1 / 1,000,000$ estimated prevalence at birth [10]. This disorder is caused by HSD3B2 gene
Henrik Falhammar

henrik.falhammar@ki.se

1 Department of Medicine, Sultan Qaboos University Hospital, Muscat, Oman

2 Division of Medicine, Royal Darwin Hospital, Darwin, NT, Australia

3 Department of Women's and Children's Health, Karolinska Institutet, Stockholm, Sweden
4 Department of Paediatric Endocrinology, Astrid Lindgren Children Hospital, Karolinska University Hospital, Stockholm, Sweden

5 Department of Endocrinology, Metabolism and Diabetes, Karolinska University Hospital, Stockholm, Sweden

6 Department of Molecular Medicine and Surgery, Karolinska Institutet, Stockholm, Sweden

7 Menzies School of Health Research, Darwin, NT, Australia 
Fig. 1 a Normal steroidogenesis in the adrenal cortex. The pathways of aldosterone, cortisol, and androgen synthesis and the enzymatic steps from the precursor cholesterol are shown. b Adrenal hormonal synthesis and enzyme expression pattern. ZG zona glomerulosa, ZF zona fasciculata, ZR zona reticularis, CYP11B2 aldosterone synthase, CYP17A1 17 $\alpha$-hydroxylase/ 17,20-lyase, CYP11B1 11 $\beta$ hydroxylase, CYB5A, cytochrome b5, SULTA1 steroid sulfotransferase type $2 \mathrm{~A} 1$
A

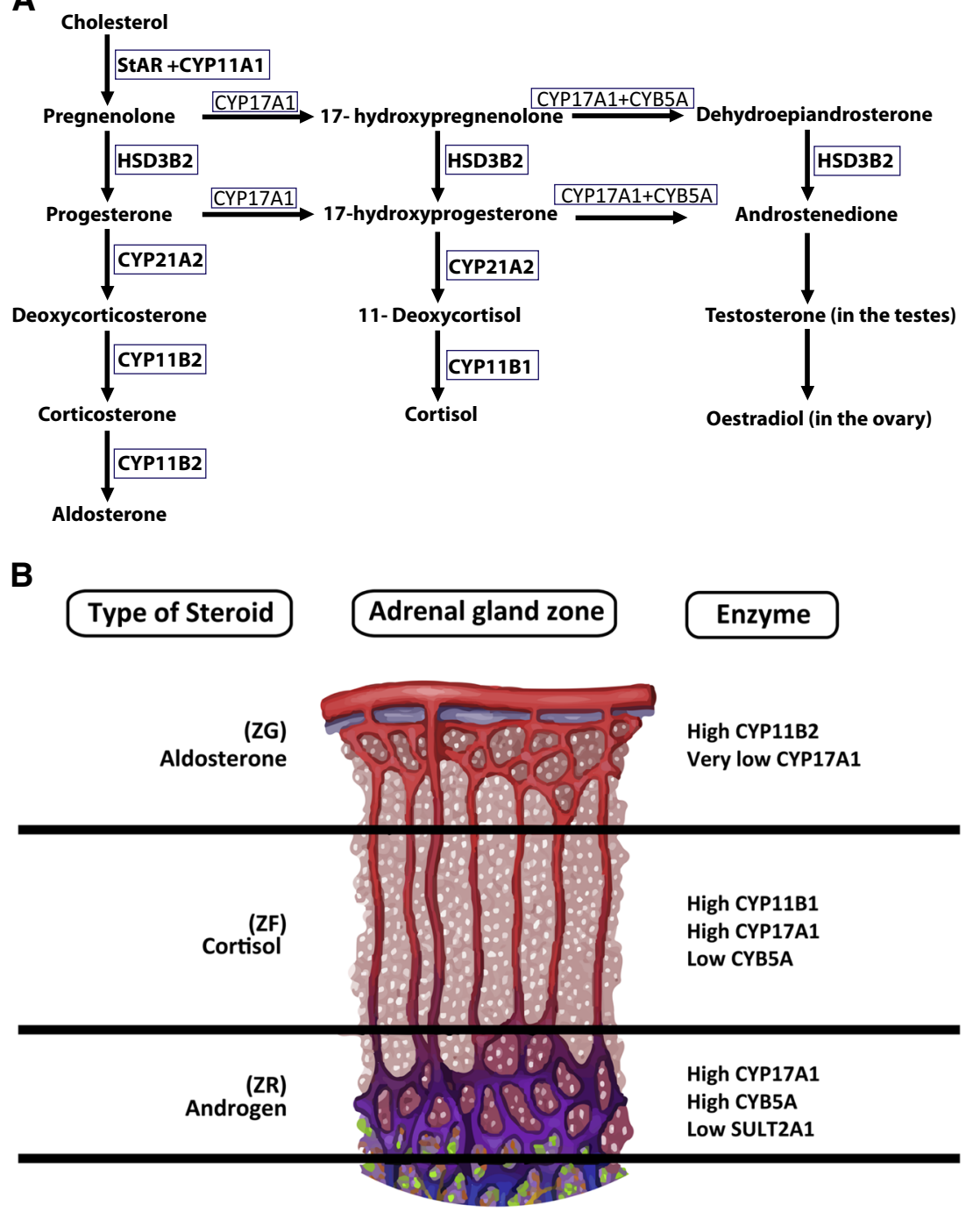

mutations and characterized by impairment of steroid synthesis in the gonads and the adrenal glands [11]. This leads to decreased cortisol, aldosterone, and androstenedione concentrations, however, renin, ACTH, and dehydroepiandrosterone (DHEA) concentrations are increased with DHEA being converted to testosterone by extra-adrenal 3 $\beta$ HSD1 [2]. The first cases of $3 \beta \mathrm{HSD} 2 \mathrm{D}$ were reported by Bongiovanni in USA 1962 [12]. The clinical presentation varies according to the type (severity) of the genetic mutation and may include salt-wasting (SW) in both sexes, incomplete masculinization in males, and virilization in females. Elevated $\Delta 5$-17-hydroxypregnenolone is the best single biological marker or indicator of $3 \beta \mathrm{HSD} 2 \mathrm{D}$ [13], but molecular genetic testing is recommended to confirm the diagnosis [14]. Glucorticoid and mineralocorticoid replacement therapy constitutes the main treatment [15]. In addition, sex hormones may be required for some patients who fail to progress through puberty [16].

The aim of this review is to provide a summary of currently available knowledge of $\mathrm{CAH}$ due to $3 \beta \mathrm{HSD} 2 \mathrm{D}$.

\section{Physiology}

The adrenal glands are vital organs where steroidogenesis (in adrenal cortex) and catecholamine production (adrenal medulla) take place. The adrenal cortex has three compartments: zona glomerulosa, zona fasciculata, and zona reticularis [17] (Fig. 1). In the first step of the steroidogenesis StAR transports the cholesterol across the membrane, and then cholesterol is converted pregnenolone by the P450 side chain cleavage enzyme [18]. Within the zona glomerulosa, HSD3B2 converts pregnenolone to progesterone, which eventually is converted into aldosterone by a series of enzymatic processes involving CYP21A2 and aldosterone synthase [17]. In the zona fasciculata, CYP17A1 hydroxylates pregnenolone to form 17-hydroxyprogesterone (17OHP) which is then converted via several enzymes, including CYP11B1 and HSD3B2, to form cortisol. In the zona reticularis, 17-hydroxypregnenolone is converted to DHEA by CYP17A1. Then, HSD3B2 converts DHEA to 


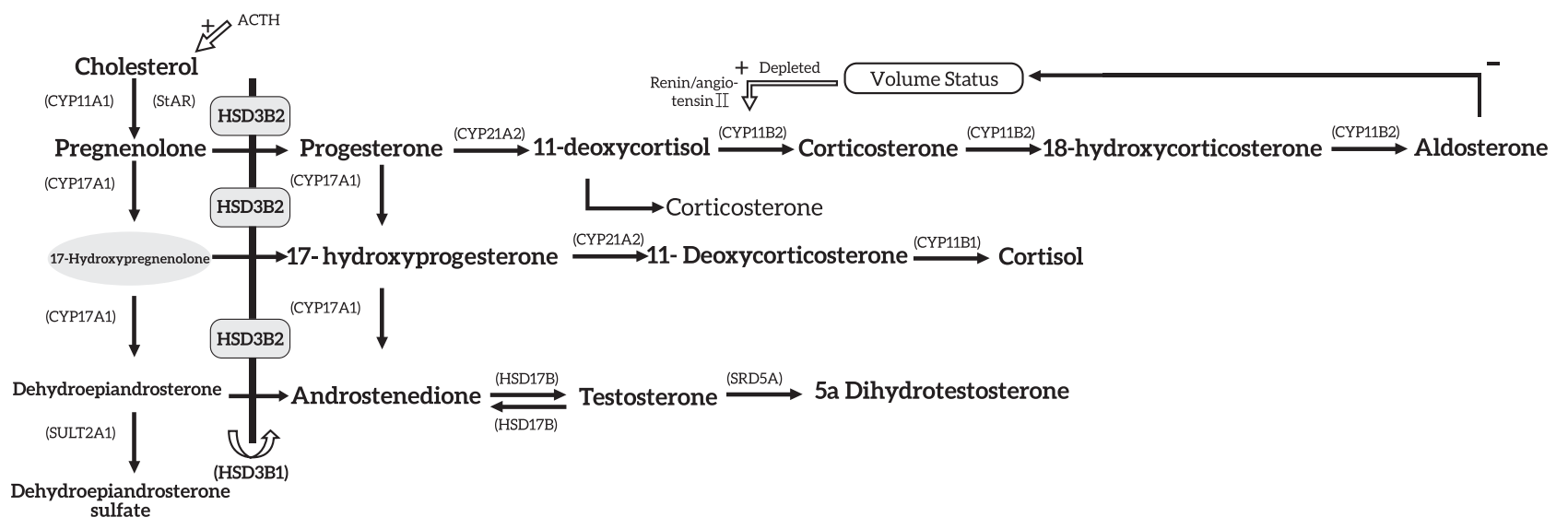

Fig. 2 Pathophysiology in 3 $\beta$-hydroxysteroid dehydrogenase type 2 deficiency

androstenedione, which is a precursor of sex hormones [18]. The conversion of the $\Delta 5-3 \beta$-hydroxysteroids (pregnenolone, 17-hydroxypregnenolone, and DHEA) to a $\Delta 4-3$ ketosteroids (progesterone, 17OHP, and androstenedione) by HSD3B2 involves dehydrogenation followed by an isomerization reaction [19]. Similarly, within the Leydig cells in the testis, cholesterol is converted to pregnenolone, 17hydroxypregnenolone, DHEA and androstenedione. HSD17B3/AKR1C3 converts androstenedione or androstenediol to testosterone [20]. DHEA is converted by SULT2A1 to the more stable sulfated form (DHEAS). DHEAS has longer half-life $(<10 \mathrm{~h})$ and only $20 \%$ diurnal variation (DHEA $\sim 30 \mathrm{~min}$ and $300 \%$, respectively) [21] and is therefore measured more often than DHEA, for practical reasons. DHEAS can then be reconverted to DHEA by steroid sulfatase (STS) $(\sim 70 \%)$ but also to a certain degree by SULT2A1 located in the liver and kidney [22, 23].

\section{Pathophysiology}

21OHD and 11OHD impair steroidogenesis in the adrenal glands only [1-3, 6, 17]. In contrast, severe form of $3 \beta$ HSD2D causes defects of steroidogenesis in both adrenal glands and gonads [2, 3, 15]. Figure 2 illustrates the pathophysiology of 3 $\beta \mathrm{HSD} 2 \mathrm{D}$.

HSD3B2 catalyzes reactions responsible for synthesis of a 3-keto- $\Delta 4$ A-ring, which is an essential part of endogenous mineralocorticoids, glucocorticoids, progestins, and androgens $[3,12,24]$. As a result, $3 \beta \mathrm{HSD} 2 \mathrm{D}$ impairs the synthesis of progesterone, the precursor hormone of aldosterone, 17OHP, the precursor for cortisol, androstenedione, testosterone, and estrogen in the adrenal glands and gonads [13, 24]. Reduced levels of cortisol decrease the negative feedback on the pituitary gland causing excess ACTH production. Subsequently, ACTH drives the accumulation of $\beta$-hydroxy- $\Delta 5$-steroids pregnenolone, 17- hydroxypregnenolone, and DHEA, and their sulfates [25]. These precursor steroids cannot compensate for the cortisol and aldosterone deficiencies resulting in electrolyte disturbances and SW in most patients [12]. In the peripheral tissues, the intact isoenzyme HSD3B1 enzyme converts circulating DHEA to testosterone [16].

Elevated level of androstenedione leads to relatively high level of testosterone in females, however, it fails to achieve full compensation for absence of testosterone synthesis in males. In 46,XY neonates testosterone deficiency causes genital ambiguity. On the other hand, in 46,XX neonates, the relatively high level of testosterone may cause clitoromegaly and partial labioscrotal fusion. In addition, undiagnosed females may present with precocious pubarche, acne, hirsutism, and menstrual disturbances [26].

The human type I isoenzyme $3 \beta \mathrm{HSD}$ is the isoenzyme, encoded by $H S D 3 B 1$ gene and is expressed in peripheral tissue including skin, mammary glands, and placenta $[9,11$, 14]. It has 372 amino acids and shares more than $90 \%$ homology with the type II isoenzyme [27, 28]. The human type I isoenzyme $3 \beta \mathrm{HSD}$ catalyzes transformation of DHEA into sex steroids including testosterone and estradiol [9].

\section{Clinical presentation}

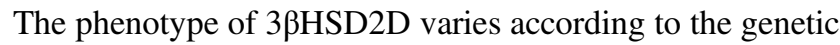
defect from severe SW form in neonates to mild menstrual disorders in older females [13, 15, 20].

\section{Incomplete masculinization in males}

In normal 46,XY fetuses, androgens are required for penile development including the urethra and fusion of the labialscrotal folds that normally takes place before 12 weeks of

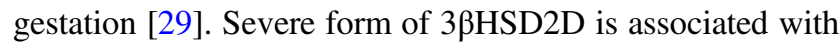
varying manifestations of incomplete masculinization 
including severe hypospadia, micropenis, bifid scrotum, and undescended testis [16, 20, 29].

\section{Female virilization}

Depending on the genetic mutations, 46,XX infants can show enlarged clitoris, incomplete labial fusion and genital hyperpigmentation [30]. In contrast, some girls can have normal external genitalia which may delay diagnosis and they can subsequently present with adrenal crisis [31]. Older girls and women with genetically confirmed non-SW $3 \beta \mathrm{HSD} 2 \mathrm{D}$ can present with androgen symptoms of hirsutism, premature pubarche or menstrual disorders including oligomenorrhea and primary amenorrhea $[16,32]$.

\section{Salt-wasting}

Several deleterious mutations in the HSD3B2 gene have been described that can cause SW during the first few weeks of life and may be fatal if not treated adequately [31, 32]. Biochemical findings include hyponatremia, hyperkalemia, metabolic acidosis and hypoglycemia [15, 33]. On the other hand, missense mutations in the coding region of HSD3B2 gene is associated with non-SW form due to the presence of some residual enzymatic activity, about $10 \%$, is sufficient to prevent aldosterone deficiency [16, 24, 32, 34, 35].

\section{Hypoglycemia}

Recurrent episodes of hypoglycemia were reported to be a presenting feature in a suspected case of $3 \beta \mathrm{HSD} 2 \mathrm{D}$ but the genotype was not performed to confirm the diagnosis [36]. Another patient presented during second day of life with hypoglycemia, later on, the molecular genetics confirmed 3ßHSD2D [31].

\section{Diagnosis}

In case of SW phenotype, 3 $\beta \mathrm{HSD} 2 \mathrm{D}$ is usually diagnosed within the first few weeks of life. In case of non-SW phenotype, patients may be diagnosed at any time before puberty [37]. However, the diagnosis has rarely been further delayed and patients can present with gender role related concerns during adulthood [38]. Overall, the patients tend to be diagnosed at a younger age in $46, \mathrm{XY}$ children due to a higher rate of genital ambiguity compared to females [34, 39]. Also, there seems to be an underrepresentation of 46 , XX patients, which might be explained by lack of diagnosis in milder form of 3 $\beta$ HSD2D in females. Also, females with severe form may die undiagnosed in a neonatal adrenal crisis more often than males [15].

When adrenal insufficiency is suspected in the setting of an adrenal crisis (i.e., an acute hemodynamic disturbance with hyponatremia, hyperkalemia and often hypoglycemia), blood should be drawn for steroid hormone measurements [15], but without delaying the lifesaving acute treatment with intravenous (or intramuscular) hydrocortisone [40, 41]. Low cortisol with high ACTH is consistent with primary adrenal insufficiency [42].

As $3 \beta \mathrm{HSD} 2 \mathrm{D}$ catalyzes the conversion of $\Delta 5$-steroids (pregnenolone, 17-hydroxypregnenolone, DHEA, androstenediol) to $\Delta 4$-steroids (progesteron, $17 \mathrm{OHP}$, androstenedione, testosterone), the main hormonal changes observed in patients with $3 \beta \mathrm{HSD} 2 \mathrm{D}$ are high ratios of the $\Delta 5$ - over $\Delta 4$-steroids $[24,43]$. This includes raised 17hydroxypregnenolone to 17OHP and DHEA(S) to androstenedione ratios in serum, and pregnanetriol to pregnanediol ratio in urine $[15,44,45]$.

\section{ACTH stimulation test and hormonal profiles}

Morning administration of $250 \mu \mathrm{g}$ of synthetic ACTH followed by measurements of plasma $\Delta 5$-17-hydroxypregnenolone (5-17P), cortisol, $\Delta 4$-17-hydroxyprogesterone (17OHP), DHEA(S), and androstenedione can be used to improve the diagnostic process of $3 \beta \mathrm{HSD} 2 \mathrm{D}[3,13]$. Hormonal criteria for the diagnosis of 3 $\beta \mathrm{HSD} 2 \mathrm{D}$ have been developed from a previous study [13], where hormonal profiles of patients with homozygous/compound heterogeneous $H S D 3 B 2$ mutations and people with normal HSD $3 B 2$ genes were compared. ACTH stimulation test shows, apart from diminished cortisol, an exaggerated response and high level of $\Delta 5$-17-hydroxypregnenolone in patients with homozygous/compound heterozygous $H S D 3 B 2$ mutations and varies according to patient age (Table 1) [13, 46].

In general, $\Delta 5$-17-hydroxypregnenolone above 100 $\mathrm{nmol} / \mathrm{L}$, either basal or after ACTH stimulation, is the best

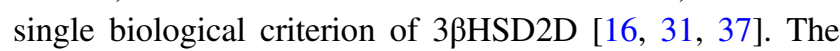
hormonal profile cannot distinguish heterozygous carriers from normal people [3, 47].

Other biochemical findings are elevated renin, relatively high level of testosterone in girls, elevated 17OHP (via peripheral conversion, see below), elevated DHEA(S), elevated urinary $\Delta 5$-OHP, and DHA metabolites [16].

Table 1 Post ACTH stimulation test of $\Delta 5$-17-hydroxypregnenolone in patients with $3 \beta \mathrm{HSD} 2 \mathrm{D}$ confirmed by $H S D 3 B 2$ mutation analysis [13]

Neonates with ambiguous genitalia $\geq 378 \mathrm{nmol} / \mathrm{L}$

Tanner stage I children with ambiguous genitalia $\geq 165 \mathrm{nmol} / \mathrm{L}$ Children with premature pubarche $\geq 294 \mathrm{nmol} / \mathrm{L}$ Adults $\geq 289 \mathrm{nmol} / \mathrm{L}$ 


\section{Molecular analysis and genetic studies}

There are two isoenzymes of human $3 \beta \mathrm{HSD}$ which are encoded by different genes located on the p13.1 region of chromosome $1[14,15]$. Both genes are included within a DNA fragment of around $7.8 \mathrm{kB}$ and consist of four exons and three introns $[19,24,34]$. The $H S D 3 B 2$ gene encodes the human type II $3 \beta \mathrm{HSD}$ isoenzyme and is expressed in the adrenal cortex and in the gonads. The isoenzyme is essential for the adrenal synthesis of glucocorticoids, mineralocorticoids, and sex steroids [9, 10, 34, 36]. More than 40 mutations have been found in the HSD3B2 gene causing $3 \beta \mathrm{HSD} 2 \mathrm{D}$ and a few of them have been identified in isolated populations (Table 2) [10, 15, 16, 20, 24, 29-31, 35, 37, 48-64].

In general, frameshift mutations, in-frame deletions, and nonsense mutations introducing a premature termination codon are associated with severe form of 3 $3 \mathrm{HSD} 2 \mathrm{D}$ resulting in SW phenotype [14, 34, 65]. The locations of these mutations suggest that at least the first 318 amino acids out of 371 are required for HSD3B2 activity [14]. In contrast, missense mutations are associated with some residual enzymatic activity and non-SW phenotype [14]. There have been no reported mutations of the $H S D 3 B 1$ gene in human so far $[32,44]$.

\section{Neonatal screening}

Newborns with atypical external genitalia should undergo hormonal profile analysis prior to hospital discharge to avoid presentation with SW crisis [66, 67]. Neonatal screening for $21 \mathrm{OHD}$ by detecting elevated level of $17 \mathrm{OHP}$ has been implemented in most developed countries [68]. $3 \beta \mathrm{HSD} 2 \mathrm{D}$ can result in an increase in the level of circulating 17OHP due to peripheral conversion of high levels of accumulated $\Delta 5$-steroids by the isoenzyme $3 \beta \mathrm{HSD}$ type 1 . There have been previous case reports of false positive, for 21OHD, neonatal screen for infants with 3 $\beta$ HSD2D [31, 65]. Accordingly, neonates with elevated 17OHP should undergo molecular genetic confirmation to confirm the type of enzymatic deficiency [14, 31, 68].

\section{Non-classic form of 3 $\beta$ HSD2D}

Prior to the implementation of molecular genetic studies, it was thought that many children with premature pubarche, and females with hirsutism and menstrual irregularities might have a mild, late-onset (non-classic) form of 33HSD2D [35, 37, 45]. This was supported by controversial hormonal criteria based on exaggerated $\Delta 5$ steroid production after ACTH stimulation test and elevated $17 \mathrm{OHP}$ to cortisol ratios [32]. However, genetic studies failed to detect any mutations in the HSD $3 B 2$ gene in this group of patients [24, 29, 35, 37], and treatment with glucocorticoids and mineralocorticoids did not improve signs of androgen excess [29, 32]. A previous report has shown normalization of the hormonal profile after treatment with GnRH agonist for two patients diagnosed with polycystic ovarian syndrome (PCOS)

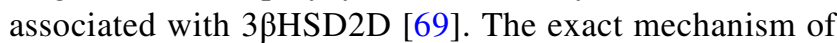
exaggerated $\Delta 5$-steroid production after ACTH stimulation is not clear and it might be related to a form of PCOS or other unidentified mechanism causing alteration in intra-adrenal $3 \beta \mathrm{HSD}$ activity [32]. A not uncommon presentation among adult women with mild hyperandrogenism is that they are found to have elevated serum DHEAS and/or reported to have "partial 33HSD2D", based on urine steroid profiling but with no HSD $3 B 2$ gene mutations identified. The diagnosis usually ends up being PCOS. Thus, non-classic 3 $\beta$ HSD2D, if it exists, is extremely rare [2], in contrast to non-classic $21 \mathrm{OHD}$ $[70,71]$.

\section{Pubertal status}

Few patients have been evaluated after puberty $[15,20,33$, 72-75]. With good compliance with glucocortiocid and mineralocorticoid replacement therapy [15], most 46,XX patients have shown progressive feminization at appropriate age with menstruations [15, 33, 74]. In contrast, one female with severe $H S D 3 B 2$ mutations had minimal breast development at age 14.7 years, required gonadotropin injections and estrogen treatment to develop full feminization. However, with cessation of estrogen and progesterone replacement treatment, her menstrual cycle ceased and she developed ovarian cysts [16, 76].

The pubertal development has been reported in some males with $H S D 3 B 2$ mutations. Most of these patients entered puberty spontaneously without need for testosterone supplementation [15, 20, 33, 72, 74, 75, 77]. This could be explained by peripheral conversion of DHEAS to testosterone by HSD17B5 activity [10, 20].

\section{Gynecomastia}

In adult males with $3 \beta \mathrm{HSD} 2 \mathrm{D}$, HSD3B1 converts the high amount of androgen precursors (DHEA and androstenediol) in peripheral tissues to androstenedione or testosterone [20]. Then HSD17B1, HSD17B5, and CYP19A1 enzymes catalyze the conversion of androstenedione and testosterone to estrogens [20]. High level of estrogens is associated with gynecomastia in males [10, 20, 72]. Testosterone replacement therapy was found to reduce gynecomastia by suppressing gonadotrophin synthesis via negative feedback [20]. 
Table 2 HSD3B2 gene mutations causing 3 3 -hydroxysteroid dehydrogenase type 2 deficiency

\begin{tabular}{|c|c|c|c|c|}
\hline Mutation/genotype & Sex & Clinical presentation & Comments & $\begin{array}{l}\text { First author } \\
\text { [reference] }\end{array}$ \\
\hline $\begin{array}{l}\text { Homozygous mutation } \\
\text { c. } 73 \mathrm{G}>\mathrm{T}(\mathrm{p} . \mathrm{E} 25 \mathrm{X})\end{array}$ & Female & $\begin{array}{l}\text { SW } \\
\text { Mild virilization }\end{array}$ & & Huang [61] \\
\hline (L205P, p.Leu205Pro) & Male & $\begin{array}{l}\text { SW } \\
\text { Hyperpigmentation } \\
\text { Severe hypospadias } \\
\text { Bifid scrotum }\end{array}$ & $\begin{array}{l}\text { No detectable } \\
\text { 3ßHSD activity }\end{array}$ & Moisan [16] \\
\hline $\begin{array}{l}\text { Compound heterogeneous } \\
\text { mutation 186/insC/187 and } \\
\text { (Y253N, p.Tyr253Asn) }\end{array}$ & Male & $\begin{array}{l}\text { SW } \\
\text { Severe undervirilization } \\
\text { Hypospadia }\end{array}$ & $\begin{array}{l}\text { Frames shift, } \\
\text { missense } \\
\text { No detectable } \\
\text { 3ßHSD activity }\end{array}$ & Simard [24, 29] \\
\hline $\begin{array}{l}\text { Compound heterogeneous } \\
\text { mutation: W171X/(E142K, p. } \\
\text { Glu142Lys) }\end{array}$ & Male & $\begin{array}{l}\text { SW } \\
\text { Severe undervirilization } \\
\text { Hypospadia }\end{array}$ & $\begin{array}{l}\text { Nonsense, } \\
\text { missense } \\
\text { No detectable } \\
\text { 3ßHSD activity }\end{array}$ & Simard [24, 29] \\
\hline (A82P, p.Ala82Pro) & Male & $\begin{array}{l}\text { SW } \\
\text { Perineal hypospadias }\end{array}$ & & Rabbani [60] \\
\hline $\begin{array}{l}\text { Homozygous mutation } \\
687 \mathrm{del} 27\end{array}$ & Male & $\begin{array}{l}\text { Neonatal SW } \\
\text { Micropenis with a } \\
\text { perineal hypospadias }\end{array}$ & $\begin{array}{l}\text { Achieved normal } \\
\text { puberty } \\
\text { Adult spermatic } \\
\text { characteristics were } \\
\text { normal }\end{array}$ & Donadille [10] \\
\hline $\begin{array}{l}687 \text { del } 27 \text { homozygous } \\
\text { mutation }\end{array}$ & Male & $\begin{array}{l}\text { Perineal hypospadias } \\
\text { Miropenis } \\
\text { SW }\end{array}$ & $\begin{array}{l}\text { No detectable } \\
\text { 3ßHSD activity }\end{array}$ & Moisan [16] \\
\hline Homozygous c.687del27 & Male & $\begin{array}{l}\text { Severe undervirilization } \\
\text { Low steroid production } \\
\text { Arrested } \\
\text { spermatogenesis } \\
\text { Gynecomastia }\end{array}$ & & $\begin{array}{l}\text { Burckhardt } \\
\text { [20] }\end{array}$ \\
\hline $\begin{array}{l}\text { Compound heterogeneous } \\
\text { mutation } 318 \text { [ACA (Thr)] - } \\
\text { >AA } 273[\text { AAA(Lys) } \longrightarrow \text { A] }\end{array}$ & Female & $\begin{array}{l}\text { SW } \\
\text { Sexual ambiguity }\end{array}$ & & Zhang [30] \\
\hline \multirow[t]{2}{*}{ (T259M, p.Thr259Met) } & Male & $\begin{array}{l}\text { Perineal hypospadia } \\
\text { Bifid scrotum } \\
\text { SW }\end{array}$ & $\begin{array}{l}\text { No detectable } \\
\text { 3ßHSD activity }\end{array}$ & Moisan [16] \\
\hline & Female & $\begin{array}{l}\text { Mild clitromegaly } \\
\text { Premature pubarche }\end{array}$ & & Marui [35] \\
\hline \multirow[t]{2}{*}{ (T259R, p.Thr259Arg) } & Male & $\begin{array}{l}\text { Pigmentation } \\
\text { Hypospadias } \\
\text { Bifid scrotum } \\
\text { SW }\end{array}$ & $\begin{array}{l}\text { No detectable } \\
3 \beta \text { HSD activity }\end{array}$ & Moisan [16] \\
\hline & Female & $\begin{array}{l}\text { Normal genitalia with } \\
\text { severe pigmentation } \\
\text { SW }\end{array}$ & & \\
\hline $\begin{array}{l}\text { Compound heterozygote A82D, } \\
\text { W230X }\end{array}$ & Female & $\begin{array}{l}\text { Hypoglycemia } \\
\text { SW }\end{array}$ & & $\begin{array}{l}\text { Nordenstrom } \\
{[31]}\end{array}$ \\
\hline (P222Q, p.Pro222Gln) & Male & $\begin{array}{l}\text { Perineal hypospadias } \\
\text { Micropenis } \\
\text { SW }\end{array}$ & $\begin{array}{l}\text { No detectable } \\
\text { 3ßHSD activity }\end{array}$ & Moisan [16] \\
\hline (P155L, p.Pro155Leu) & Male & $\begin{array}{l}\text { Perineal hypospadias } \\
\text { SW }\end{array}$ & $\begin{array}{l}\text { No detectable } \\
3 \beta \mathrm{HSD} \text { activity }\end{array}$ & Moisan [16] \\
\hline $\begin{array}{l}\text { Homozygous p.W355R (c.763 } \\
\mathrm{T}>\mathrm{C} \text { ) }\end{array}$ & Male & $\begin{array}{l}\text { Hypospadias } \\
\text { cryptorchidism } \\
\text { Bifid scrotum } \\
\text { SW }\end{array}$ & TART & Guven [63] \\
\hline
\end{tabular}


Table 2 (continued)

\begin{tabular}{|c|c|c|c|c|}
\hline Mutation/genotype & Sex & Clinical presentation & Comments & $\begin{array}{l}\text { First author } \\
\text { [reference] }\end{array}$ \\
\hline \multirow[t]{2}{*}{ (A10E, p.Ala10Glu) } & Male & $\begin{array}{l}\text { Sexual ambiguity } \\
\text { SW } \\
\text { Azoospermia }\end{array}$ & Missense & Alos [15] \\
\hline & Female & $\begin{array}{l}\text { Normal genitalia } \\
\text { SW/normal puberty }\end{array}$ & & \\
\hline \multirow[t]{2}{*}{$\begin{array}{l}\text { Homozygous p.Q334X } \\
\text { (c.1000C }>T)\end{array}$} & Male & $\begin{array}{l}\text { SW } \\
\text { Hypospadias, small } \\
\text { phallus, bifid scrotae, } \\
\text { palpable gonads }\end{array}$ & TART & Alswailem [28] \\
\hline & Female & $\begin{array}{l}\text { SW } \\
\text { Normal genitalia }\end{array}$ & & \\
\hline \multirow[t]{2}{*}{ p.R335X (c.1003C>T) } & Male & $\begin{array}{l}\text { SW } \\
\text { Hypospadias } \\
\text { Bifid scrota } \\
\text { Palpable gonads } \\
\text { Advanced bone } \\
\text { maturation }\end{array}$ & Bilateral TARTs & \\
\hline & Female & $\begin{array}{l}\text { SW } \\
\text { Normal genitalia }\end{array}$ & & \\
\hline W171X :Trp171 Stop & Female & $\begin{array}{l}\text { SW } \\
\text { Normal external } \\
\text { genitilia } \\
\text { Failure of breast } \\
\text { development }\end{array}$ & Nonsense & Rheaume [11] \\
\hline $\begin{array}{l}\text { Compound heterogenous } \\
\text { mutation W171X: Trp171 Stop } \\
\text { and 186/insC/187 }\end{array}$ & Male & $\begin{array}{l}\text { SW } \\
\text { Hypospadias }\end{array}$ & $\begin{array}{l}\text { Nonsense } \\
\text { Adequate } \\
\text { spermatogenesis }\end{array}$ & Rheaume [11] \\
\hline $273 \Delta \mathrm{AA}$ & Male & $\begin{array}{l}\text { SW } \\
\text { Ambiguous genitalia }\end{array}$ & $\begin{array}{l}\text { Frameshift } \\
\text { mutation } \\
\text { No residual } \\
\text { enzymatic activity }\end{array}$ & Simard [48] \\
\hline $\begin{array}{l}\text { Compound heterogenous } \\
\text { mutation (L108W, p. } \\
\text { Leu108Trp) (P186L, p. } \\
\text { Pro186Leu) }\end{array}$ & Male & $\begin{array}{l}\text { SW } \\
\text { Hypospadias }\end{array}$ & $\begin{array}{l}\text { Missense } \\
\text { Less than } 0.5 \% \\
\text { enzymatic activity }\end{array}$ & Sanchez [53] \\
\hline (G15D, p.Gly15Asp) & Male & $\begin{array}{l}\text { SW } \\
\text { Hypospadias }\end{array}$ & Missense & Rheaume [49] \\
\hline $\begin{array}{l}\text { Compound heterozygous for } \\
\text { T181I1 and 1105delA }\end{array}$ & Female & $\begin{array}{l}\text { SW } \\
\text { Premature pubarche, } \\
\text { slight growth } \\
\text { acceleration, and } \\
\text { advanced bone age }\end{array}$ & Frameshift & Johannsen [37] \\
\hline (P222T, p.Pro222Thr) & Female & SW & Missense & Pang [58] \\
\hline (P341L, p.Pro341Leu) & Male & $\begin{array}{l}\text { SW } \\
\text { Micropenis }\end{array}$ & & Welzel [59] \\
\hline $\begin{array}{l}\text { Heterozygosity.244G }>A(p . \\
\text { Ala82Thr), } 931 \mathrm{C}>\mathrm{T}(\mathrm{p} . \\
\text { Gln311*) }\end{array}$ & Female & Ambiguous genitalia & & Teasdale [64] \\
\hline (S213G, p.Ser213Gly) & Female & $\begin{array}{l}\text { Premature pubarche at } 4 \\
\text { y } \\
\text { Growth acceleration }\end{array}$ & Detectable activity & Moisan [16] \\
\hline (A245P, p.Ala245Pro) & Male & Sexual ambiguity & Detectable activity & Simard $[24,29]$ \\
\hline (A10V, p.Ala10Val) & Male & $\begin{array}{l}\text { Perinoscrotal } \\
\text { hypospadia }\end{array}$ & $\begin{array}{l}\text { Detectable activity } \\
(30 \%)\end{array}$ & Moisan [16] \\
\hline
\end{tabular}


Table 2 (continued)

\begin{tabular}{|c|c|c|c|c|}
\hline Mutation/genotype & Sex & Clinical presentation & Comments & $\begin{array}{l}\text { First author } \\
\text { [reference] }\end{array}$ \\
\hline \multirow[t]{2}{*}{ (L236S, p.Leu236Ser) } & Male & $\begin{array}{l}\text { Perinoscrota } \\
\text { hypospadias } \\
\text { Micropenis }\end{array}$ & Missense & Moisan [16] \\
\hline & Female & Premature pubarche & Missense & Nayak [57] \\
\hline (A245):Ala245Pro & Male & $\begin{array}{l}\text { Hypospadias } \\
\text { Bifid scrotum }\end{array}$ & $\begin{array}{l}\text { Missense } \\
\text { Detectable } \\
\text { enzymatic activity }\end{array}$ & Simard [24] \\
\hline (G129R, p.Gly129Arg) & $\begin{array}{l}\text { Male } \\
\text { Female }\end{array}$ & $\begin{array}{l}\text { Perineal hypospadias } \\
\text { Normal genitalia } \\
\text { Premature pubarche }\end{array}$ & $\begin{array}{l}\text { Missense/splice } \\
\text { Detectable } \\
\text { enzymatic activity }\end{array}$ & Rheaume [51] \\
\hline (N100S, p.Asn100Ser) & Male & Perineal hypospadias & Missense & Mebarki [55] \\
\hline (Y254D, p.Tyr254Asp) & Female & $\begin{array}{l}\text { Severe acne } \\
\text { Primary amenorrhea } \\
\text { Clitoromegaly } \\
\text { Moderate hirsutism }\end{array}$ & Missense & Sanchez [54] \\
\hline (L173R, p.Leu173Arg) & Male & Perineal hypospadias & $\begin{array}{l}\text { Missense } \\
\text { Raised as female }\end{array}$ & Russel [52] \\
\hline \multirow[t]{2}{*}{ (A82T, p.Ala82Thr) } & Female & $\begin{array}{l}\text { Some with no signs of } \\
\text { CAH } \\
\text { One patient with } \\
\text { premature pubarche }\end{array}$ & Missense & Mendonca [50] \\
\hline & Male & Perineal hypospadias & & \\
\hline p.G250V & Female & $\begin{array}{l}\text { Precocious pubarche } \\
\text { Postnatal clitoromegaly }\end{array}$ & & $\begin{array}{l}\text { Baquedano } \\
{[62]}\end{array}$ \\
\hline (A167V, p.Ala167Val) & Female & Premature pubarche & Missense & Moisan [16] \\
\hline (K216E, p.Lys216Glu) & Female & Premature pubarche & Missense & Moisan [16] \\
\hline (P22H, p.Pro221His) & Female & Premature pubarche & & Moisan [16] \\
\hline (G294V, p.Gly294Val) & Male & Hypospadias & & Moisan [16] \\
\hline
\end{tabular}

SW Salt wasting

\section{Final height}

Final height has been reported in a few patients and the adult height seemed to be within the target range when control of the hyperandrogenism during the growth period had been good [15], but otherwise the final height was reduced [75].

\section{Fertility}

$3 \beta \mathrm{HSD}$ is required for biosynthesis of not only mineralocorticoids and glucocorticoids, but also sex hormones. Accordingly, males with $3 \beta \mathrm{HSD} 2 \mathrm{D}$ may suffer from decreased spermatogenesis and infertility. Also, females may have menstrual irregularity and infertility [20]. However, there is very limited information about fertility, semen

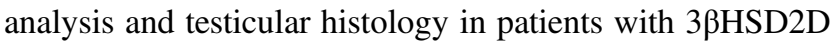
$[15,20,73,75]$. In case reports of $46, X Y$ patients, semen analyses have shown azoospermia [15, 75]. Moreover, testicular histology in adult males with 3 $\beta$ HSD2D showed spermatogenic arrest at the level of spermatogonia [20,78]. In contrast, a patient with severe $H S D 3 B 2$ mutations, with annual follow-ups from birth until the age of 23 years old, demonstrated normal sperm production probably attributed to his good compliance with treatment [10]. This might suggest that fertility is possible even with severe mutations. One case of an adult male fathering two children has been reported, however, there was no genetic testing to confirm his paternity [10]. In 21OHD, fertility has been shown to be impaired in both females and males [4, 79-86], however, the fertility may be normal if the male has been diagnosed and treated early on since the neonatal period. If this is also true in $3 \beta \mathrm{HSD} 2 \mathrm{D}$ is unknown.

\section{Testicular adrenal rest tumors}

During abdominal surgery, the presence of ectopic adrenocortical tissue is a common incidental finding in otherwise healthy individuals without clinical significance [87]. In patients with $\mathrm{CAH}$ and during period of suboptimal 
treatment, high levels of ACTH and angiotensin II can stimulate adrenal-like cells causing development of testicular adrenal rest tumors (TARTs) and rarely ovarian adrenal rest tumors $[75,87]$. The prevalence of TARTs varies between 34 and $94 \%$ according to different reports in males with $\mathrm{CAH}$ due to $210 \mathrm{OHD}[82,85,88,89]$. TARTs have been reported in some patients with $3 \beta \mathrm{HSD} 2 \mathrm{D}[15,63,75]$, but it is difficult to estimate the prevalence. Also, it has been demonstrated that presence of TARTs has a negative impact on fertility in males with $210 H D$ [82, 88, 90]. Similarly, in previous case reports, males with $3 \beta$ HSD2D and TARTs have been found to have severely impaired spermatogenesis $[63,75,82]$. High dose of corticosteroids might reduce the size of TART [63]. It has been recommended that all patients with $\mathrm{CAH}$ should undergo regular testicular examination with ultrasonography $[1,7,90]$. Even though these recommendations were primarily written for $210 \mathrm{HD}$ it can be assumed that males with $3 \beta$ HSD2D have equal benefits.

\section{Bone mineral density and fractures}

Supraphysiological glucocorticoid replacement has harmful effects on bone mineral density (BMD) via multiple

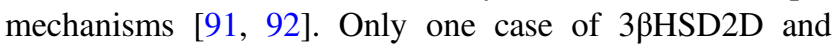
BMD measurements has been reported, and has showed osteoporosis [75]. In general, studies in adults with $\mathrm{CAH}$ have demonstrated impaired BMD [4, 93-100], even though there are exceptions with normal BMD [101, 102], and better than other DSD conditions [103]. Prednisolone may be associated with worse BMD than hydrocortisone [95, 97, 104, 105]. Fractures have not been reported in $3 \beta \mathrm{HSD} 2 \mathrm{D}$ so far but may be increased in $\mathrm{CAH}$ in general [93, 95, 97, 99, 100, 103].

\section{Obesity, diabetes, and cardiovascular disease}

Obesity, including severe, has been reported in patients with $3 \beta$ HSD2D [63, 75], probably due to iatrogenic Cushing syndrome. It could be assumed that the prevalence of obesity, diabetes and cardiovascular disease in 3 3 HSD2D is similar to most other forms of $\mathrm{CAH}$, most commonly 210HD, and mainly due to glucocorticoid excess but androgen excess and/or deficiency may also contribute. The majority of studies including adults and children with $\mathrm{CAH}$ have reported an increased body fat mass assessed by DXA [96, 101, 102, 106, 107], which enables separation between lean mass (which may be increased due to hyperandrogenism) from fat mass. Elevated cardiometabolic risk, including insulin resistance [4, 94, 108-117], has been reported in a large number of studies on $\mathrm{CAH}$, with a few reporting increased rate of established cardiovascular disease [103, 118], and diabetes (including gestational diabetes) [81, 109, 118]. Very few individuals with $\mathrm{CAH}$ above 50 years of age have been included in studies, and thus it could be expected that the rate will increase since cardiovascular disease and diabetes usually develop later in life [1].

\section{Psychiatric diseases}

Psychiatric disorders have so far not been reported in studies with exclusively 3 $\beta$ HSD2D recruited [119]. In studies of CAH psychiatric diseases have only occasionally been investigated and these have shown an increased rate [103, $120,121]$, especially of depression [122], alcohol misuse [120, 121], and suicidality [103, 120].

\section{Adrenal tumors}

Chronic elevation of ACTH will lead to hyperplasia of the adrenal cortex and sometimes subsequent tumor formation [123-125]. Adrenal tumors have so far not been reported in $3 \beta \mathrm{HSD} 2 \mathrm{D}$ but are known to affect $11-82 \%$ of patients with other CAH variants [124, 126, 127]. Adrenal incidentalomas, i.e., adrenal tumors found serendipitously by imaging for other reasons than suspected adrenal tumor or disease [128], have sometimes been the initial presentation of $\mathrm{CAH}$, including classic $\mathrm{CAH}$, both in case reports and adrenal incidentaloma cohorts [125, 129-134].

\section{Mortality}

Very little is known about the mortality in individuals with $3 \beta H S D 2 D$. The introduction of glucocorticoid replacement and increased awareness have increased the survival of classic 21OHD [5], and this is most probably also the case in $3 \beta \mathrm{HSD} 2 \mathrm{D}$. In population studies, patients with $\mathrm{CAH}$ had generally an increased mortality rate (hazard ratio 3-5) and died 6.5-18 years earlier, compared to controls [122, 135]. Adrenal crisis was the main cause of death [135], iterating the importance of stress dosing during acute illness [40, 41]. Mortality studies in pure $3 \beta$ HSD2D will probably never be performed due to its rareness.

\section{Treatment}

Glucocorticoid and mineralocorticoid replacement is similar to other forms of CAH. In SW crisis, treatment includes prompt rehydration, correction of hypoglycemia, and parenteral hydrocortisone (intravenous or intramuscular) [15, 40, 41]. For follow-up children are treated with hydrocortisone in a dose of $10-15 \mathrm{mg} / \mathrm{m}^{2} /$ day. Long-acting glucocorticoids such as dexamethasone and prednisolone, known to suppress growth in children, can be used during adulthood [7, 33, 67]. Compared to 21OHD it seems to be 
more difficult to suppress the androgens in 3ßHSD2D, which could be speculated be due to the DHEAS as a constant source of DHEA, testosterone and DHT. This may result in a need for slightly higher doses of glucocorticoids in 3 $3 \mathrm{HSD} 2 \mathrm{D}$ with subsequently more long-term negative outcomes. Mineralocorticoid replacement can be achieved with fludrocortisone $0.1 \mathrm{mg} /$ day [33] with regular monitoring of plasma renin activity [1, 7, 67]. Sex hormone replacement therapy should be considered for patients who show delayed progression through puberty [16]. In addition, testosterone replacement therapy might be considered for male patients with testosterone responsive microphallus to augment penile growth [33]. Hormonal replacement therapy should be combined with regular clinical and biochemical evaluation of these patients [15]. Surgical intervention might be indicated in some circumstances including undescended testis [63], hypospadias repair [20], and severe genital virilization [136-138]. Bilateral adrenalectomy has occasionally been used in selective cases with 210HD or $11 \mathrm{OHD}$ to better control hyperandrogenism and/or to be able to lower the glucocorticoid doses with similar control of the hyperandrogenism [139]. Its utility in $3 \beta \mathrm{HSD} 2 \mathrm{D}$ is currently unclear.

\section{Conclusion}

$3 \beta H S D 2 D$ is a very rare form of $\mathrm{CAH}$ and the phenotype varies according to the severity of the HSD $3 B 2$ mutations. In severe forms, the neonate can present with SW crisis but the diagnosis can be delayed in mild forms until adolescence. Hormonal criteria for the diagnosis of $3 \beta \mathrm{HSD} 2 \mathrm{D}$ have been developed and it was proposed that $\Delta 5$-17-hydroxypregnenolone above $100 \mathrm{nmol} / \mathrm{L}$, either basal or after ACTH stimulation, is the best single biological criterion of $3 \beta \mathrm{HSD} 2 \mathrm{D}$. However, molecular genetic testing is recommended to confirm the diagnosis. Glucocorticoid and mineralocorticoid replacement are the main treatments. Sex hormone replacement and surgical corrective procedures may be indicated in some patients. On the basis of case reports, $3 \beta \mathrm{HSD} 2 \mathrm{D}$ may be associated with infertility, obesity, osteoporosis, TARTs, and reduced final height. However, very little is known about mortality, cardiovascular health, mental health, and

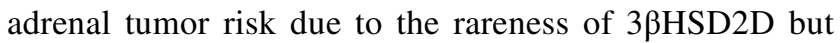
can be presumed to be elevated, and similar to 21OHD. Although in $3 \beta \mathrm{HSD} 2 \mathrm{D}$ it seems to be more difficult to suppress the androgens, subsequently leading to slightly higher glucocorticoid doses. This may result in more long-term negative outcomes.

Funding This study was funded by Magnus Bergvall Foundation (Grant Number 2017-02138).

\section{Compliance with ethical standards}

Conflict of interest The authors declare that they have no conflict of interest.

Publisher's note: Springer Nature remains neutral with regard to jurisdictional claims in published maps and institutional affiliations.

Open Access This article is distributed under the terms of the Creative Commons Attribution 4.0 International License (http://crea tivecommons.org/licenses/by/4.0/), which permits use, duplication, adaptation, distribution, and reproduction in any medium or format, as long as you give appropriate credit to the original author(s) and the source, provide a link to the Creative Commons license, and indicate if changes were made.

\section{References}

1. H. Falhammar, M. Thoren, Clinical outcomes in the management of congenital adrenal hyperplasia. Endocrine 41(3), 355-373 (2012). https://doi.org/10.1007/s12020-011-9591-x

2. D. El-Maouche, W. Arlt, D.P. Merke, Congenital adrenal hyperplasia. Lancet 390(10108), 2194-2210 (2017). https://doi. org/10.1016/S0140-6736(17)31431-9

3. W.L. Miller, Mechanisms in endocrinology: rare defects in adrenal steroidogenesis. Eur. J. Endocrinol. 179(3), R125-R141 (2018). https://doi.org/10.1530/EJE-18-0279

4. W. Arlt, D.S. Willis, S.H. Wild, N. Krone, E.J. Doherty, S. Hahner, T.S. Han, P.V. Carroll, G.S. Conway, D.A. Rees, R.H. Stimson, B.R. Walker, J.M. Connell, R.J. Ross, United Kingdom Congenital Adrenal Hyperplasia Adult Study, Executive: Health status of adults with congenital adrenal hyperplasia: a cohort study of 203 patients. J. Clin. Endocrinol. Metab. 95(11), 5110-5121 (2010). https://doi.org/10.1210/jc.2010-0917

5. S. Gidlof, H. Falhammar, A. Thilen, U. von Dobeln, M. Ritzen, A. Wedell, A. Nordenstrom, One hundred years of congenital adrenal hyperplasia in Sweden: a retrospective, population-based cohort study. Lancet Diabetes Endocrinol. 1(1), 35-42 (2013). https://doi.org/10.1016/S2213-8587(13)70007-X

6. K. Bulsari, H. Falhammar, Clinical perspectives in congenital adrenal hyperplasia due to 11 beta-hydroxylase deficiency. Endocrine 55(1), 19-36 (2017). https://doi.org/10.1007/s12020016-1189-x

7. P.W. Speiser, W. Arlt, R.J. Auchus, L.S. Baskin, G.S. Conway, D.P. Merke, H.F.L. Meyer-Bahlburg, W.L. Miller, M.H. Murad, S.E. Oberfield, P.C. White, Congenital adrenal hyperplasia due to steroid 21-hydroxylase deficiency: an endocrine society clinical practice guideline. J. Clin. Endocrinol. Metab. 103(11), 4043-4088 (2018). https://doi.org/10.1210/jc.2018-01865

8. N.A. Al-Jurayyan, Ambiguous genitalia: two decades of experience. Ann. Saudi Med. 31(3), 284-288 (2011). https://doi. org/10.4103/0256-4947.81544

9. A.R. Benkert, M. Young, D. Robinson, C. Hendrickson, P.A. Lee, K.A. Strauss, Severe salt-losing 3beta-hydroxysteroid dehydrogenase deficiency: treatment and outcomes of HSD3B2 c.35G>A homozygotes. J. Clin. Endocrinol. Metab. 100(8), E1105-E1115 (2015). https://doi.org/10.1210/jc.20152098

10. B. Donadille, M. Houang, I. Netchine, J.P. Siffroi, S. ChristinMaitre, Human 3beta-hydroxysteroid dehydrogenase deficiency associated with normal spermatic numeration despite a severe enzyme deficit. Endocr. Connect 7(3), 395-402 (2018). https:// doi.org/10.1530/EC-17-0306 
11. E. Rheaume, J. Simard, Y. Morel, F. Mebarki, M. Zachmann, M. G. Forest, M.I. New, F. Labrie, Congenital adrenal hyperplasia due to point mutations in the type II 3 beta-hydroxysteroid dehydrogenase gene. Nat. Genet 1(4), 239-245 (1992). https:// doi.org/10.1038/ng0792-239

12. A.M. Bongiovanni, The adrenogenital syndrome with deficiency of 3 beta-hydroxysteroid dehydrogenase. J. Clin. Invest. 41, 2086-2092 (1962). https://doi.org/10.1172/JCI104666

13. C. Lutfallah, W. Wang, J.I. Mason, Y.T. Chang, A. Haider, B. Rich, M. Castro-Magana, K.C. Copeland, R. David, S. Pang, Newly proposed hormonal criteria via genotypic proof for type II 3beta-hydroxysteroid dehydrogenase deficiency. J. Clin. Endocrinol. Metab. 87(6), 2611-2622 (2002). https://doi.org/10.1210/ jcem.87.6.8615

14. Y. Morel, F. Mebarki, E. Rheaume, R. Sanchez, M.G. Forest, J. Simard, Structure-function relationships of 3 betahydroxysteroid dehydrogenase: contribution made by the molecular genetics of 3 beta-hydroxysteroid dehydrogenase deficiency. Steroids 62(1), 176-184 (1997)

15. N. Alos, A.M. Moisan, L. Ward, M. Desrochers, L. Legault, G. Leboeuf, G. Van Vliet, J. Simard, A novel A10E homozygous mutation in the HSD3B2 gene causing severe salt-wasting 3betahydroxysteroid dehydrogenase deficiency in $46, \mathrm{XX}$ and $46, \mathrm{XY}$ French-Canadians: evaluation of gonadal function after puberty. J. Clin. Endocrinol. Metab. 85(5), 1968-1974 (2000). https://doi. org/10.1210/jcem.85.5.6581

16. A.M. Moisan, M.L. Ricketts, V. Tardy, M. Desrochers, F. Mebarki, J.L. Chaussain, S. Cabrol, M.C. Raux-Demay, M.G. Forest, W.G. Sippell, M. Peter, Y. Morel, J. Simard, New insight into the molecular basis of 3beta-hydroxysteroid dehydrogenase deficiency: identification of eight mutations in the HSD3B2 gene eleven patients from seven new families and comparison of the functional properties of twenty-five mutant enzymes. J. Clin. Endocrinol. Metab. 84(12), 4410-4425 (1999). https://doi.org/ 10.1210/jcem.84.12.6288

17. A.F. Turcu, R.J. Auchus, Adrenal steroidogenesis and congenital adrenal hyperplasia. Endocrinol. Metab. Clin. North Am. 44(2), 275-296 (2015). https://doi.org/10.1016/j.ecl.2015.02.002

18. S.F. Witchel, Congenital adrenal hyperplasia. J. Pediatr. Adolesc. Gynecol. 30(5), 520-534 (2017). https://doi.org/10.1016/j.jpag. 2017.04.001

19. A.H. Payne, D.B. Hales, Overview of steroidogenic enzymes in the pathway from cholesterol to active steroid hormones. Endocr. Rev. 25(6), 947-970 (2004). https://doi.org/10.1210/er.2003-0030

20. M.A. Burckhardt, S.S. Udhane, N. Marti, I. Schnyder, C. Tapia, J.E. Nielsen, P.E. Mullis, E. Rajpert-De Meyts, C.E. Fluck, Human 3beta-hydroxysteroid dehydrogenase deficiency seems to affect fertility but may not harbor a tumor risk: lesson from an experiment of nature. Eur. J. Endocrinol. 173(5), K1-K12 (2015). https://doi.org/10.1530/EJE-15-0599

21. L. Starka, M. Duskova, M. Hill, Dehydroepiandrosterone: a neuroactive steroid. J. Steroid Biochem Mol. Biol. 145, 254-260 (2015). https://doi.org/10.1016/j.jsbmb.2014.03.008

22. S. Sharp, E.V. Barker, M.W. Coughtrie, P.R. Lowenstein, R. Hume, Immunochemical characterisation of a dehydroepiandrosterone sulfotransferase in rats and humans. Eur. J. Biochem 211(3), 539-548 (1993)

23. C. Longcope, Dehydroepiandrosterone metabolism. J. Endocrinol. 150(Suppl), S125-127 (1996)

24. J. Simard, E. Rheaume, R. Sanchez, N. Laflamme, Y. de Launoit, V. Luu-The, A.P. van Seters, R.D. Gordon, M. Bettendorf, U. Heinrich et al.. Molecular basis of congenital adrenal hyperplasia due to 3 beta-hydroxysteroid dehydrogenase deficiency. Mol. Endocrinol. 7(5), 716-728 (1993). https://doi.org/10.1210/ mend.7.5.8316254
25. S. Pang, Congenital adrenal hyperplasia owing to 3 betahydroxysteroid dehydrogenase deficiency. Endocrinol. Metab. Clin. North Am. 30(1), 81-99 (2001).

26. A.M. Bongiovanni, A.W. Root, The adrenogenital syndrome. N. Engl. J. Med 268, 1283-1289 (1963). https://doi.org/10.1056/ NEJM196306062682308.

27. M. Doi, Y. Takahashi, R. Komatsu, F. Yamazaki, H. Yamada, S. Haraguchi, N. Emoto, Y. Okuno, G. Tsujimoto, A. Kanematsu, O. Ogawa, T. Todo, K. Tsutsui, G.T. van der Horst, H. Okamura, Salt-sensitive hypertension in circadian clock-deficient Cry-null mice involves dysregulated adrenal Hsd3b6. Nat. Med. 16(1), 67-74 (2010). https://doi.org/10.1038/nm.2061

28. M.M. Alswailem, O.S. Alzahrani, D.S. Alhomaidah, R. Alasmari, E. Qasem, A.K. Murugan, A. Alsagheir, I. Brema, B.B. Abbas, M. Almehthel, A. Almeqbali, A.S. Alzahrani, Mutational analysis of rare subtypes of congenital adrenal hyperplasia in a highly inbred population. Mol. Cell. Endocrinol. 461, 105-111 (2018). https://doi.org/10.1016/j.mce.2017.08.022

29. J. Simard, E. Rheaume, F. Mebarki, R. Sanchez, M.I. New, Y. Morel, F. Labrie, Molecular basis of human 3 betahydroxysteroid dehydrogenase deficiency. J. Steroid Biochem Mol. Biol. 53(1-6), 127-138 (1995)

30. L. Zhang, H. Sakkal-Alkaddour, Y.T. Chang, X. Yang, S. Pang, A new compound heterozygous frameshift mutation in the type II 3 beta-hydroxysteroid dehydrogenase ( 3 beta-HSD) gene causes salt-wasting 3 beta-HSD deficiency congenital adrenal hyperplasia. J. Clin. Endocrinol. Metab. 81(1), 291-295 (1996). https://doi.org/10.1210/jcem.81.1.8550766

31. A. Nordenstrom, M.G. Forest, A. Wedell, A case of 3betahydroxysteroid dehydrogenase type II (HSD3B2) deficiency picked up by neonatal screening for 21-hydroxylase deficiency: difficulties and delay in etiologic diagnosis. Horm. Res. 68(4), 204-208 (2007). https://doi.org/10.1159/000102593

32. S. Pang, The molecular and clinical spectrum of 3betahydroxysteroid dehydrogenase deficiency disorder. Trends Endocrinol. Metab. 9(2), 82-86 (1998)

33. B.S. Bin-Abbas, N.A. Sakati, A.A. Al-Ashwal, Congenital adrenal hyperplasia due to 3 beta-hydroxysteroid dehydrogenase type II deficiency in 4 Saudi children. Long term follow up. Saudi Med J. 25(9), 1293-1295 (2004)

34. J. Simard, R. Sanchez, F. Durocher, E. Rheaume, C. Turgeon, Y. Labrie, V. Luu-The, F. Mebarki, Y. Morel, Y. de Launoit et al.. Structure-function relationships and molecular genetics of the 3 beta-hydroxysteroid dehydrogenase gene family. J. Steroid Biochem Mol. Biol. 55(5-6), 489-505 (1995)

35. S. Marui, A.J. Russell, F.J. Paula, I. Dick-de-Paula, J.A. Marcondes, B.B. Mendonca, Genotyping of the type II 3betahydroxysteroid dehydrogenase gene (HSD3B2) in women with hirsutism and elevated ACTH-stimulated delta(5)-steroids. Fertil. Steril. 74(3), 553-557 (2000)

36. M.C. Konar, S. Goswami, B.G. Babu, A.K. Mallick, Hypoglycemia due to 3beta-hydroxysteroid dehydrogenase type II deficiency in a newborn. Indian Pediatr. 52(11), 981-983 (2015)

37. T.H. Johannsen, D. Mallet, H. Dige-Petersen, J. Muller, K.M. Main, Y. Morel, M.G. Forest, Delayed diagnosis of congenital adrenal hyperplasia with salt wasting due to type II 3betahydroxysteroid dehydrogenase deficiency. J. Clin. Endocrinol. Metab. 90(4), 2076-2080 (2005). https://doi.org/10.1210/jc. 2004-1374

38. B.B. Mendonca, W. Bloise, I.J. Arnhold, M.C. Batista, S.P. Toledo, M.C. Drummond, W. Nicolau, E. Mattar, Male pseudohermaphroditism due to nonsalt-losing 3 beta-hydroxysteroid dehydrogenase deficiency: gender role change and absence of gynecomastia at puberty. J. Steroid Biochem. 28(6), 669-675 (1987) 
39. B.B. Mendonca, M.C. Batista, I.J. Arnhold, W. Nicolau, G. Madureira, V.S. Lando, M.B. Kohek, D.G. Carvalho, W. Bloise, Male pseudohermaphroditism due to 5 alpha reductase deficiency associated with gynecomastia. Rev. Hosp. Clin. Fac. Med. 42(2), 66-68 (1987)

40. R.L. Rushworth, D.J. Torpy, H. Falhammar, Adrenal crises: perspectives and research directions. Endocrine 55(2), 336-345 (2017). https://doi.org/10.1007/s12020-016-1204-2

41. R.L. Rushworth, D.J. Torpy, C.A. Stratakis, H. Falhammar, Adrenal crises in children: perspectives and research directions. Horm. Res. Paediatr. 89(5), 341-351 (2018). https://doi.org/10. $1159 / 000481660$

42. S.R. Bornstein, B. Allolio, W. Arlt, A. Barthel, A. Don-Wauchope, G.D. Hammer, E.S. Husebye, D.P. Merke, M.H. Murad, C.A. Stratakis, D.J. Torpy, Diagnosis and treatment of primary adrenal insufficiency: an endocrine society clinical practice guideline. J. Clin. Endocrinol. Metab. 101(2), 364-389 (2016). https://doi.org/10.1210/jc.2015-1710

43. A. Kulle, N. Krone, P.M. Holterhus, G. Schuler, R.F. Greaves, A. Juul, Y.B. de Rijke, M.F. Hartmann, A. Saba, O. Hiort, S.A. Wudy, E.C. Action, Steroid hormone analysis in diagnosis and treatment of DSD: position paper of EU COST Action BM 1303 'DSDnet'. Eur. J. Endocrinol. 176(5), P1-P9 (2017). https://doi.org/10.1530/EJE-16-0953

44. C.E. Fluck, A.V. Pandey, Steroidogenesis of the testis-new genes and pathways. Ann. Endocrinol. 75(2), 40-47 (2014). https://doi.org/10.1016/j.ando.2014.03.002

45. M. Gortakowski, R. Conroy, L. Aguiar, H. Allen, Premature pubarche in a child with abnormal 3beta-hydroxysteroid dehydrogenase function and Klinefelter syndrome: the intriguing relationship between androgen deficiency and excess. Clin. Case Rep. 5(1), 57-60 (2017). https://doi.org/10.1002/ccr3.742

46. L.M. Mermejo, L.L. Elias, S. Marui, A.C. Moreira, B.B. Mendonca, M. de Castro, Refining hormonal diagnosis of type II 3beta-hydroxysteroid dehydrogenase deficiency in patients with premature pubarche and hirsutism based on HSD3B2 genotyping. J. Clin. Endocrinol. Metab. 90(3), 1287-1293 (2005). https://doi.org/10.1210/jc.2004-1552

47. S. Pang, G. Carbunaru, A. Haider, K.C. Copeland, Y.T. Chang, C. Lutfallah, J.I. Mason, Carriers for type II 3betahydroxysteroid dehydrogenase (HSD3B2) deficiency can only be identified by HSD3B2 genotype study and not by hormone test. Clin. Endocrinol. 58(3), 323-331 (2003)

48. J. Simard, E. Rheaume, J.F. Leblanc, S.C. Wallis, G.F. Joplin, S. Gilbey, J. Allanson, G. Mettler, M. Bettendorf, U. Heinrich et al.. Congenital adrenal hyperplasia caused by a novel homozygous frameshift mutation 273 delta $\mathrm{AA}$ in type II 3 betahydroxysteroid dehydrogenase gene (HSD3B2) in three male patients of Afghan/Pakistani origin. Human Mol. Genet. 3(2), 327-330 (1994)

49. E. Rheaume, R. Sanchez, F. Mebarki, E. Gagnon, J.C. Carel, J.L. Chaussain, Y. Morel, F. Labrie, J. Simard, Identification and characterization of the G15D mutation found in a male patient with 3 beta-hydroxysteroid dehydrogenase ( 3 beta-HSD) deficiency: alteration of the putative NAD-binding domain of type II 3 beta-HSD. Biochemistry 34(9), 2893-2900 (1995)

50. B.B. Mendonca, A.J. Russell, M. Vasconcelos-Leite, I.J. Arnhold, W. Bloise, B.L. Wajchenberg, W. Nicolau, R.G. Sutcliffe, A.M. Wallace, Mutation in 3 beta-hydroxysteroid dehydrogenase type II associated with pseudohermaphroditism in males and premature pubarche or cryptic expression in females. J. Mol. Endocrinol. 12(1), 119-122 (1994)

51. E. Rheaume, R. Sanchez, J. Simard, Y.T. Chang, J. Wang, S. Pang, F. Labrie, Molecular basis of congenital adrenal hyperplasia in two siblings with classical nonsalt-losing 3 betahydroxysteroid dehydrogenase deficiency. J. Clin. Endocrinol.
Metab. 79(4), 1012-1018 (1994). https://doi.org/10.1210/jcem. 79.4.7962268

52. A.J. Russell, A.M. Wallace, M.G. Forest, M.D. Donaldson, C.R. Edwards, R.G. Sutcliffe, Mutation in the human gene for 3 betahydroxysteroid dehydrogenase type II leading to male pseudohermaphroditism without salt loss. J. Mol. Endocrinol. 12(2), 225-237 (1994)

53. R. Sanchez, F. Mebarki, E. Rheaume, N. Laflamme, M.G. Forest, F. Bey-Omard, M. David, Y. Morel, F. Labrie, J. Simard, Functional characterization of the novel L108W and P186L mutations detected in the type II 3 beta-hydroxysteroid dehydrogenase gene of a male pseudohermaphrodite with congenital adrenal hyperplasia. Human Mol. Genet. 3(9), 1639-1645 (1994)

54. R. Sanchez, E. Rheaume, N. Laflamme, R.L. Rosenfield, F. Labrie, J. Simard, Detection and functional characterization of the novel missense mutation Y254D in type II 3 betahydroxysteroid dehydrogenase ( 3 beta HSD) gene of a female patient with nonsalt-losing 3 beta HSD deficiency. J. Clin. Endocrinol. Metab. 78(3), 561-567 (1994). https://doi.org/10. 1210/jcem.78.3.8126127

55. F. Mebarki, R. Sanchez, E. Rheaume, N. Laflamme, J. Simard, M.G. Forest, F. Bey-Omar, M. David, F. Labrie, Y. Morel, Nonsalt-losing male pseudohermaphroditism due to the novel homozygous N100S mutation in the type II 3 betahydroxysteroid dehydrogenase gene. J. Clin. Endocrinol. Metab. 80(7), 2127-2134 (1995). https://doi.org/10.1210/jcem. 80.7.7608265

56. T. Tajima, K. Fujieda, J. Nakae, N. Shinohara, M. Yoshimoto, T. Baba, E. Kinoshita, Y. Igarashi, T. Oomura, Molecular analysis of type II 3 beta-hydroxysteroid dehydrogenase gene in Japanese patients with classical 3 beta-hydroxysteroid dehydrogenase deficiency. Hum. Mol. Genet 4(5), 969-971 (1995)

57. S. Nayak, P.A. Lee, S.F. Witchel, Variants of the type II 3betahydroxysteroid dehydrogenase gene in children with premature pubic hair and hyperandrogenic adolescents. Mol. Genet Metab. 64(3), 184-192 (1998). https://doi.org/10.1006/mgme.1998.2715

58. S. Pang, W. Wang, B. Rich, R. David, Y.T. Chang, G. Carbunaru, S.E. Myers, A.F. Howie, K.J. Smillie, J.I. Mason, A novel nonstop mutation in the stop codon and a novel missense mutation in the type II 3beta-hydroxysteroid dehydrogenase (3beta-HSD) gene causing, respectively, nonclassic and classic 3beta-HSD deficiency congenital adrenal hyperplasia. J. Clin. Endocrinol. Metab. 87(6), 2556-2563 (2002). https://doi.org/10. 1210/jcem.87.6.8559

59. M. Welzel, N. Wustemann, G. Simic-Schleicher, H.G. Dorr, E. Schulze, G. Shaikh, P. Clayton, J. Grotzinger, P.M. Holterhus, F. G. Riepe, Carboxyl-terminal mutations in 3beta-hydroxysteroid dehydrogenase type II cause severe salt-wasting congenital adrenal hyperplasia. J. Clin. Endocrinol. Metab. 93(4), 1418-1425 (2008). https://doi.org/10.1210/jc.2007-1874

60. B. Rabbani, N. Mahdieh, M.T. Haghi Ashtiani, A. Setoodeh, A. Rabbani, In silico structural, functional and pathogenicity evaluation of a novel mutation: an overview of HSD3B2 gene mutations. Gene 503(2), 215-221 (2012). https://doi.org/10. 1016/j.gene.2012.04.080

61. Y. Huang, J. Zheng, T. Xie, Q. Xiao, S. Lu, X. Li, J. Cheng, L. Chen, L. Liu, [A novel homozygous mutation p.E25X in the HSD3B2 gene causing salt wasting 3beta-hydroxysteroid dehydrogenases deficiency in a Chinese pubertal girl: a delayed diagnosis until recurrent ovary cysts]. Zhonghua Er Ke Za Zhi 52 (12), 948-951 (2014)

62. M.S. Baquedano, M. Ciaccio, R. Marino, N. Perez Garrido, P. Ramirez, M. Maceiras, A. Turjanski, L.A. Defelipe, M.A. Rivarola, A. Belgorosky, A novel missense mutation in the HSD3B2 gene, underlying nonsalt-wasting congenital adrenal hyperplasia. new insight into the structure-function relationships of 
3beta-hydroxysteroid dehidrogenase type II. J. Clin. Endocrinol. Metab. 100(1), E191-E196 (2015). https://doi.org/10.1210/jc. 2014-2676

63. A. Guven, S. Polat, Testicular Adrenal rest tumor in two brothers with a novel mutation in the 3-beta-hydroxysteroid dehydrogenase-2 gene. J. Clin. Res Pediatr. Endocrinol. 9(1), 85-90 (2017). https://doi.org/10.4274/jcrpe.3306

64. S.L. Teasdale, A. Morton, Adrenarche unmasks compound heterozygous 3beta-hydroxysteroid dehydrogenase deficiency: c.244G $>$ A (p.Ala82Thr) and the novel 931C $>$ T (p.Gln311*) variant in a non-salt wasting, severely undervirilised 46XY. J. Pediatr. Endocrinol. Metab. 30(3), 355-360 (2017). https://doi. org/10.1515/jpem-2016-0348

65. V. G. Araújo, R. S. Oliveira, K. P. Gameleira, C. B. Cruz, A. Lofrano-Porto, 3 $\beta$-hydroxysteroid dehydrogenase type II deficiency on newborn screening test. Arq. Bras. Endocrinol. Metab. 58(6), 650-655 (2014). https://doi.org/10.1590/00042730000003098

66. C. Bizzarri, N. Olivini, S. Pedicelli, R. Marini, G. Giannone, P. Cambiaso, M. Cappa, Congenital primary adrenal insufficiency and selective aldosterone defects presenting as salt-wasting in infancy: a single center 10-year experience. Ital. J. Pediatr. 42(1), 73 (2016). https://doi.org/10.1186/s13052-016-0282-3

67. R. Podgorski, D. Aebisher, M. Stompor, D. Podgorska, A. Mazur, Congenital adrenal hyperplasia: clinical symptoms and diagnostic methods. Acta Biochim. Pol. 65(1), 25-33 (2018). https://doi.org/10.18388/abp.2017_2343

68. H. Falhammar, A. Wedell, A. Nordenstrom, Biochemical and genetic diagnosis of 21-hydroxylase deficiency. Endocrine 50(2), 306-314 (2015). https://doi.org/10.1007/s12020-015-0731-6

69. F. Gonzalez, D.A. Hatala, L. Speroff, Adrenal and ovarian steroid hormone responses to gonadotropin-releasing hormone agonist treatment in polycystic ovary syndrome. Am. J. Obstet. Gynecol. 165(3), 535-545 (1991)

70. H. Falhammar, A. Nordenstrom, Nonclassic congenital adrenal hyperplasia due to 21-hydroxylase deficiency: clinical presentation, diagnosis, treatment, and outcome. Endocrine 50(1), 32-50 (2015). https://doi.org/10.1007/s12020-015-0656-0

71. F. Hannah-Shmouni, R. Morissette, N. Sinaii, M. Elman, T.R. Prezant, W. Chen, A. Pulver, D.P. Merke, Revisiting the prevalence of nonclassic congenital adrenal hyperplasia in US Ashkenazi Jews and Caucasians. Genet Med 19(11), 1276-1279 (2017). https://doi.org/10.1038/gim.2017.46

72. P.A. Parks, G.A. Bermudez, C.S. Anast, A.M. Bongiovanni, M.I. New, Pubertal boy with the $3 \beta$-hydroxy steroid dehydrogenase defect. J. Clin. Endocrinol. Metab. 33(2), 269-278 (1971). https://doi.org/10.1210/jcem-33-2-269

73. O. Janne, J. Perheentupa, L. Viinikka, R. Vihko, Testicular endocrine function in a pubertal boy with 3beta-hydroxysteroid dehydrogenase deficiency. J. Clin. Endocrinol. Metab. 39(1), 206-209 (1974). https://doi.org/10.1210/jcem-39-1-206

74. Y.T. Chang, H.E. Kulin, L. Garibaldi, M.J. Suriano, K. Bracki, S. Pang, Hypothalamic-pituitary-gonadal axis function in pubertal male and female siblings with glucocorticoid-treated nonsalt-wasting 3 beta-hydroxysteroid dehydrogenase deficiency congenital adrenal hyperplasia. J. Clin. Endocrinol. Metab. 77 (5), 1251-1257 (1993). https://doi.org/10.1210/jcem.77.5. 8077318

75. E. Lolis, C.C. Juhlin, A. Nordenstrom, H. Falhammar, Extensive bilateral adrenal rest testicular tumors in a patient with 3betahydroxysteroid dehydrogenase type 2 deficiency. J. Endocr. Soc. 2(6), 513-517 (2018). https://doi.org/10.1210/js.2018-00082

76. M. Zachmann, M.G. Forest, E. De Peretti, 3 beta-hydroxysteroid dehydrogenase deficiency follow-study a girl pubertal bone age. Horm. Res. 11(6), 292-302 (1979). https://doi.org/10.1159/ 000179067
77. M. Yoshimoto, T. Kawaguchi, R. Mori, E. Kinoshita, T. Baba, T. Tajima, K. Fujieda, T. Suzuki, H. Sasano, Pubertal changes in testicular 3 beta-hydroxysteroid dehydrogenase activity in a male with classical 3 beta-hydroxysteroid dehydrogenase deficiency showing spontaneous secondary sexual maturation. Horm. Res. 48(2), 83-87 (1997). https://doi.org/10.1159/000185492

78. G. Schneider, M. Genel, A.M. Bongiovanni, A.S. Goldman, R.L. Rosenfield, Persistent testicular delta5-isomerase-3betahydroxysteroid dehydrogenase (delta5-3beta-HSD) deficiency in the delta5-3beta-HSD form of congenital adrenal hyperplasia. J. Clin. Invest. 55(4), 681-690 (1975). https://doi.org/10.1172/ JCI107977

79. J. Jaaskelainen, M. Hippelainen, O. Kiekara, R. Voutilainen, Child rate, pregnancy outcome and ovarian function in females with classical 21-hydroxylase deficiency. Acta Obstet. Gynecol. Scand. 79(8), 687-692 (2000)

80. F. Gastaud, C. Bouvattier, L. Duranteau, R. Brauner, E. Thibaud, F. Kutten, P. Bougneres, Impaired sexual and reproductive outcomes in women with classical forms of congenital adrenal hyperplasia. J. Clin. Endocrinol. Metab. 92(4), 1391-1396 (2007). https://doi.org/10.1210/jc.2006-1757

81. K. Hagenfeldt, P.O. Janson, G. Holmdahl, H. Falhammar, H. Filipsson, L. Frisen, M. Thoren, A. Nordenskjold, Fertility and pregnancy outcome in women with congenital adrenal hyperplasia due to 21-hydroxylase deficiency. Hum. Reprod. 23(7), 1607-1613 (2008). https://doi.org/10.1093/humrep/den118.

82. H. Falhammar, H.F. Nystrom, U. Ekstrom, S. Granberg, A. Wedell, M. Thoren, Fertility, sexuality and testicular adrenal rest tumors in adult males with congenital adrenal hyperplasia. Eur. J. Endocrinol. 166(3), 441-449 (2012). https://doi.org/10.1530/ EJE-11-0828

83. D.E. Reichman, P.C. White, M.I. New, Z. Rosenwaks, Fertility in patients with congenital adrenal hyperplasia. Fertil. Steril. 101 (2), 301-309 (2014). https://doi.org/10.1016/j.fertnstert.2013.11. 002

84. A. Strandqvist, H. Falhammar, P. Lichtenstein, A.L. Hirschberg, A. Wedell, C. Norrby, A. Nordenskjold, L. Frisen, A. Nordenstrom, Suboptimal psychosocial outcomes in patients with congenital adrenal hyperplasia: epidemiological studies in a nonbiased national cohort in Sweden. J. Clin. Endocrinol. Metab. 99(4), 1425-1432 (2014). https://doi.org/10.1210/jc.2013-3326

85. C. Bouvattier, L. Esterle, P. Renoult-Pierre, A.B. de la Perriere, F. Illouz, V. Kerlan, V. Pascal-Vigneron, D. Drui, S. ChristinMaitre, F. Galland, T. Brue, Y. Reznik, F. Schillo, D. Pinsard, X. Piguel, G. Chabrier, B. Decoudier, P. Emy, I. Tauveron, M.L. Raffin-Sanson, J. Bertherat, J.M. Kuhn, P. Caron, M. Cartigny, O. Chabre, D. Dewailly, Y. Morel, P. Touraine, V. Tardy-Guidollet, J. Young, Clinical outcome, hormonal status, gonadotrope axis, and testicular function in 219 adult men born with classic 21-hydroxylase deficiency. A French National Survey. J. Clin. Endocrinol. Metab. 100(6), 2303-2313 (2015). https://doi.org/ 10.1210/jc. 2014-4124

86. H. Falhammar, L. Frisen, C. Norrby, C. Almqvist, A.L. Hirschberg, A. Nordenskjold, A. Nordenstrom, Reduced frequency of biological and increased frequency of adopted children in males with 21-hydroxylase deficiency: a Swedish PopulationBased National Cohort Study. J. Clin. Endocrinol. Metab. 102 (11), 4191-4199 (2017). https://doi.org/10.1210/jc.2017-01139

87. H.L. Claahsen-van der Grinten, K. Duthoi, B.J. Otten, F.C. d'Ancona, C.A. Hulsbergen-vd Kaa, A.R. Hermus, An adrenal rest tumour in the perirenal region in a patient with congenital adrenal hyperplasia due to congenital 3beta-hydroxysteroid dehydrogenase deficiency. Eur. J. Endocrinol. 159(4), 489-491 (2008). https://doi.org/10.1530/EJE-08-0311

88. N.M. Stikkelbroeck, B.J. Otten, A. Pasic, G.J. Jager, C.G. Sweep, K. Noordam, A.R. Hermus, High prevalence of testicular 
adrenal rest tumors, impaired spermatogenesis, and Leydig cell failure in adolescent and adult males with congenital adrenal hyperplasia. J. Clin. Endocrinol. Metab. 86(12), 5721-5728 (2001)

89. M. Engels, K. Gehrmann, H. Falhammar, E.A. Webb, A. Nordenstrom, F.C. Sweep, P.N. Span, A.E. van Herwaarden, J. Rohayem, A. Richter-Unruh, C. Bouvattier, B. Kohler, B.B. Kortmann, W. Arlt, N. Roeleveld, N. Reisch, N. Stikkelbroeck, H.L. Claahsen-van der Grinten, Lg dsd, Gonadal function in adult male patients with congenital adrenal hyperplasia. Eur. J. Endocrinol. 178(3), 285-294 (2018). https://doi.org/10.1530/ EJE-17-0862

90. H.L. Claahsen-van der Grinten, B.J. Otten, M.M. Stikkelbroeck, F.C. Sweep, A.R. Hermus, Testicular adrenal rest tumours in congenital adrenal hyperplasia. Best. Pract. Res. Clin. Endocrinol. Metab. 23(2), 209-220 (2009). https://doi.org/10.1016/j. beem.2008.09.007.

91. G. Mazziotti, A.M. Formenti, S. Frara, E. Roca, P. Mortini, A. Berruti, A. Giustina, MANAGEMENT OF ENDOCRINE DISEASE: Risk of overtreatment in patients with adrenal insufficiency: current and emerging aspects. Eur. J. Endocrinol. 177(5), R231-R248 (2017). https://doi.org/10.1530/EJE-17-0154

92. H. Falhammar, Skeletal fragility induced by overtreatment of adrenal insufficiency. Endocrine 59(2), 239-241 (2018). https:// doi.org/10.1007/s12020-017-1501-4

93. H. Falhammar, H. Filipsson, G. Holmdahl, P.O. Janson, A. Nordenskjold, K. Hagenfeldt, M. Thoren, Fractures and bone mineral density in adult women with 21-hydroxylase deficiency. J. Clin. Endocrinol. Metab. 92(12), 4643-4649 (2007). https:// doi.org/10.1210/jc.2007-0744.

94. G.P. Finkielstain, M.S. Kim, N. Sinaii, M. Nishitani, C. Van Ryzin, S.C. Hill, J.C. Reynolds, R.M. Hanna, D.P. Merke, Clinical characteristics of a cohort of 244 patients with congenital adrenal hyperplasia. J. Clin. Endocrinol. Metab. 97(12), 4429-4438 (2012). https://doi.org/10.1210/jc.2012-2102

95. K.R. Koetz, M. Ventz, S. Diederich, M. Quinkler, Bone mineral density is not significantly reduced in adult patients on low-dose glucocorticoid replacement therapy. J. Clin. Endocrinol. Metab. 97(1), 85-92 (2012). https://doi.org/10.1210/jc.2011-2036.

96. I. Nermoen, I. Bronstad, K.J. Fougner, J. Svartberg, M. Oksnes, E.S. Husebye, K. Lovas, Genetic, anthropometric and metabolic features of adult Norwegian patients with 21-hydroxylase deficiency. Eur. J. Endocrinol. / Eur. Fed. Endocr. Soc. 167(4), 507-516 (2012). https://doi.org/10.1530/EJE-12-0196.

97. H. Falhammar, H. Filipsson Nystrom, A. Wedell, K. Brismar, M. Thoren, Bone mineral density, bone markers, and fractures in adult males with congenital adrenal hyperplasia. Eur. J. Endocrinol. 168(3), 331-341 (2013). https://doi.org/10.1530/EJE-120865

98. A. Bachelot, J.L. Golmard, J. Dulon, N. Dahmoune, M. Leban, C. Bouvattier, S. Cabrol, J. Leger, M. Polak, P. Touraine, Determining clinical and biological indicators for health outcomes in adult patients with childhood onset of congenital adrenal hyperplasia. Eur. J. Endocrinol. 173(2), 175-184 (2015). https://doi.org/10.1530/EJE-14-0978

99. D. El-Maouche, S. Collier, M. Prasad, J.C. Reynolds, D.P. Merke, Cortical bone mineral density in patients with congenital adrenal hyperplasia due to 21-hydroxylase deficiency. Clin. Endocrinol. 82(3), 330-337 (2015). https://doi.org/10.1111/cen. 12507

100. F. Ceccato, M. Barbot, N. Albiger, M. Zilio, P. De Toni, G. Luisetto, M. Zaninotto, N.A. Greggio, M. Boscaro, C. Scaroni, V. Camozzi, Long-term glucocorticoid effect on bone mineral density in patients with congenital adrenal hyperplasia due to 21hydroxylase deficiency. Eur. J. Endocrinol. 175(2), 101-106 (2016). https://doi.org/10.1530/EJE-16-0104
101. N.M. Stikkelbroeck, W.J. Oyen, G.J. van der Wilt, A.R. Hermus, B.J. Otten, Normal bone mineral density and lean body mass, but increased fat mass, in young adult patients with congenital adrenal hyperplasia. J. Clin. Endocrinol. Metab. 88(3), 1036-1042 (2003)

102. P. Christiansen, C. Molgaard, J. Muller, Normal bone mineral content in young adults with congenital adrenal hyperplasia due to 21-hydroxylase deficiency. Horm. Res. 61(3), 133-136 (2004). https://doi.org/10.1159/000075588.

103. H. Falhammar, H. Claahsen-van der Grinten, N. Reisch, J. Slowikowska-Hilczer, A. Nordenstrom, R. Roehle, C. Bouvattier, B. P.C. Kreukels, B. Kohler, Lg dsd, Health status in 1040 adults with disorders of sex development (DSD): a European multicenter study. Endocr. Connect. 7(3), 466-478 (2018). https://doi. org/10.1530/EC-18-0031

104. J. Jaaskelainen, R. Voutilainen, Bone mineral density in relation to glucocorticoid substitution therapy in adult patients with 21-hydroxylase deficiency. Clin. Endocrinol. 45(6), 707-713 (1996)

105. K.R. Frey, T. Kienitz, J. Schulz, M. Ventz, K. Zopf, M. Quinkler, Prednisolone is associated with a worse bone mineral density in primary adrenal insufficiency. Endocr. Connect. 7(6), 811-818 (2018). https://doi.org/10.1530/EC-18-0160

106. K. Hagenfeldt, E. Martin Ritzen, H. Ringertz, J. Helleday, K. Carlstrom, Bone mass and body composition of adult women with congenital virilizing 21-hydroxylase deficiency after glucocorticoid treatment since infancy. Eur. J. Endocrinol. 143(5), 667-671 (2000). 1430667 [pii]

107. A. Halper, B. Sanchez, J.S. Hodges, A.S. Kelly, D. Dengel, B.M. Nathan, A. Petryk, K. Sarafoglou, Bone mineral density and body composition in children with congenital adrenal hyperplasia. Clin. Endocrinol. 88(6), 813-819 (2018). https://doi.org/10. 1111/cen. 13580

108. H. Falhammar, H. Filipsson Nystrom, A. Wedell, M. Thoren, Cardiovascular risk, metabolic profile, and body composition in adult males with congenital adrenal hyperplasia due to 21hydroxylase deficiency. Eur. J. Endocrinol. 164(2), 285-293 (2011). https://doi.org/10.1530/EJE-10-0877.

109. H. Falhammar, H. Filipsson, G. Holmdahl, P.O. Janson, A. Nordenskjold, K. Hagenfeldt, M. Thoren, Metabolic profile and body composition in adult women with congenital adrenal hyperplasia due to 21-hydroxylase deficiency. J. Clin. Endocrinol. Metab. 92(1), 110-116 (2007). https://doi.org/10.1210/jc. 2006-1350.

110. H. Falhammar, H. Filipsson, G. Holmdahl, P.O. Janson, A. Nordenskjold, K. Hagenfeldt, M. Thoren, Increased liver enzymes in adult women with congenital adrenal hyperplasia due to 21-hydroxylase deficiency. Endocr. J. 56(4), 601-608 (2009).

111. M.F. Mnif, M. Kamoun, F. Mnif, N. Charfi, N. Kallel, B. Ben Naceur, N. Rekik, Z. Mnif, M.H. Sfar, M.T. Sfar, M. Hachicha, L.A. Keskes, M. Abid, Long-term outcome of patients with congenital adrenal hyperplasia due to 21-hydroxylase deficiency. Am. J. Med. Sci. 344(5), 363-373 (2012). https://doi.org/10. 1097/MAJ.0b013e31824369e4

112. W. Bonfig, F.W. Roehl, S. Riedl, H.G. Dorr, M. Bettendorf, J. Bramswig, E. Schonau, F. Riepe, B. Hauffa, R.W. Holl, K. Mohnike, A.C.S. Group, Blood pressure in a large cohort of children and adolescents with classic adrenal hyperplasia $(\mathrm{CAH})$ due to 21-hydroxylase deficiency. Am. J. Hypertens. 29(2), 266-272 (2016). https://doi.org/10.1093/ajh/hpv087

113. C.F. Mooij, A.E. van Herwaarden, F. Sweep, N. Roeleveld, C.L. de Korte, L. Kapusta, H.L. Claahsen-van der Grinten, Cardiovascular and metabolic risk in pediatric patients with congenital adrenal hyperplasia due to 21 hydroxylase deficiency. J. Pediatr. Endocrinol. Metab. 30(9), 957-966 (2017). https://doi.org/10. 1515/jpem-2017-0068 
114. R. Ozdemir, H.A. Korkmaz, M. Kucuk, C. Karadeniz, T. Mese, B. Ozkan, Assessment of early atherosclerosis and left ventricular dysfunction in children with 21-hydroxylase deficiency. Clin. Endocrinol. 86(4), 473-479 (2017). https://doi.org/10. $1111 /$ cen. 13275

115. C.F. Mooij, M.S. Pourier, G. Weijers, C.L. de Korte, Z. Fejzic, H.L. Claahsen-van der Grinten, L. Kapusta, Cardiac function in paediatric patients with congenital adrenal hyperplasia due to 21 hydroxylase deficiency. Clin. Endocrinol. 88(3), 364-371 (2018). https://doi.org/10.1111/cen.13529

116. D. Rosenbaum, A. Gallo, G. Lethielleux, E. Bruckert, B.I. Levy, M. L. Tanguy, J. Dulon, N. Dahmoune, J.E. Salem, R. Bittar, M. Leban, X. Girerd, P. Touraine, A. Bachelot, CARDIOHCS study group, Early central blood pressure elevation in adult patients with 21-hydroxylase deficiency. J. Hypertens. (2018). https://doi. org/10.1097/HJH.0000000000001850

117. S. Tamhane, R. Rodriguez-Gutierrez, A.M. Iqbal, L.J. Prokop, I. Bancos, P.W. Speiser, M.H. Murad, cardiovascular and metabolic outcomes in congenital adrenal hyperplasia: a systematic review and meta-analysis. J. Clin. Endocrinol. Metab. 103(11), 4097-4103 (2018). https://doi.org/10.1210/jc.2018-01862

118. H. Falhammar, L. Frisen, A.L. Hirschberg, C. Norrby, C. Almqvist, A. Nordenskjold, A. Nordenstrom, Increased cardiovascular and metabolic morbidity in patients with 21hydroxylase deficiency: a Swedish Population-Based National Cohort Study. J. Clin. Endocrinol. Metab. 100(9), 3520-3528 (2015). https://doi.org/10.1210/JC.2015-2093

119. E. Daae, K.B. Feragen, I. Nermoen, H. Falhammar, Psychological adjustment, quality of life, and self-perceptions of reproductive health in males with congenital adrenal hyperplasia: a systematic review. Endocrine 62(1), 3-13 (2018). https://doi.org/ 10.1007/s12020-018-1723-0

120. H. Falhammar, A. Butwicka, M. Landen, P. Lichtenstein, A. Nordenskjold, A. Nordenstrom, L. Frisen, Increased psychiatric morbidity in men with congenital adrenal hyperplasia due to 21hydroxylase deficiency. J. Clin. Endocrinol. Metab. 99(3), E554-E560 (2014). https://doi.org/10.1210/jc.2013-3707

121. H. Engberg, A. Butwicka, A. Nordenstrom, A.L. Hirschberg, H. Falhammar, P. Lichtenstein, A. Nordenskjold, L. Frisen, M. Landen, Congenital adrenal hyperplasia and risk for psychiatric disorders in girls and women born between 1915 and 2010: a total population study. Psychoneuroendocrinology 60, 195-205 (2015). https://doi.org/10.1016/j.psyneuen.2015.06.017

122. S. Jenkins-Jones, L. Parviainen, J. Porter, M. Withe, M.J. Whitaker, S.E. Holden, C.L. Morgan, C.J. Currie, R.J.M. Ross, Poor compliance and increased mortality, depression and healthcare costs in patients with congenital adrenal hyperplasia. Eur. J. Endocrinol. 178 (4), 309-320 (2018). https://doi.org/10.1530/EJE-17-0895

123. H. Selye, H. Stone, Hormonally induced transformation of adrenal into myeloid tissue. Am. J. Pathol. 26(2), 22 (1950)

124. S. Jaresch, E. Kornely, H.K. Kley, R. Schlaghecke, Adrenal incidentaloma and patients with homozygous or heterozygous congenital adrenal hyperplasia. J. Clin. Endocrinol. Metab. 74 (3), 685-689 (1992). https://doi.org/10.1210/jcem.74.3.1311000

125. H. Falhammar, Non-functioning adrenal incidentalomas caused by 21-hydroxylase deficiency or carrier status? Endocrine 47(1), 308-314 (2014). https://doi.org/10.1007/s12020-013-0162-1

126. N. Reisch, M. Scherr, L. Flade, M. Bidlingmaier, H.P. Schwarz, U. Muller-Lisse, M. Reincke, M. Quinkler, F. Beuschlein, Total adrenal volume but not testicular adrenal rest tumor volume is associated with hormonal control in patients with 21-hydroxylase deficiency. J. Clin. Endocrinol. Metab. 95(5), 2065-2072 (2010). https://doi.org/10.1210/jc.2009-1929
127. I. Nermoen, J. Rorvik, S.H. Holmedal, D.L. Hykkerud, K.J. Fougner, J. Svartberg, E.S. Husebye, K. Lovas, High frequency of adrenal myelolipomas and testicular adrenal rest tumours in adult Norwegian patients with classical congenital adrenal hyperplasia because of 21-hydroxylase deficiency. Clin. Endocrinol. 75(6), 753-759 (2011). https://doi.org/10.1111/j.13652265.2011.04151.x

128. J. Patrova, M. Kjellman, H. Wahrenberg, H. Falhammar, Increased mortality in patients with adrenal incidentalomas and autonomous cortisol secretion: a 13-year retrospective study from one center. Endocrine 58(2), 267-275 (2017). https://doi. org/10.1007/s12020-017-1400-8

129. L. Barzon, C. Scaroni, N. Sonino, F. Fallo, M. Gregianin, C. Macri, M. Boscaro, Incidentally discovered adrenal tumors: endocrine and scintigraphic correlates. J. Clin. Endocrinol. Metab. 83(1), 55-62 (1998)

130. A. Patocs, M. Toth, C. Barta, M. Sasvari-Szekely, I. Varga, N. Szucs, C. Jakab, E. Glaz, K. Racz, Hormonal evaluation and mutation screening for steroid 21-hydroxylase deficiency in patients with unilateral and bilateral adrenal incidentalomas. Eur. J. Endocrinol. 147(3), 349-355 (2002).

131. H. Falhammar, M. Thoren, An 88-year-old woman diagnosed with adrenal tumor and congenital adrenal hyperplasia: connection or coincidence? J. Endocrinol. Investig. 28(5), 449-453 (2005).

132. J. Patrova, I. Jarocka, H. Wahrenberg, H. Falhammar, Clinical outcomes in adrenal incidentaloma: experience from one center. Endocr. Pract. 21(8), 870-877 (2015). https://doi.org/10.4158/ EP15618.OR

133. H. Falhammar, D.J. Torpy, A 42-year-old man presented with adrenal incidentaloma due to non-classic congenital adrenal hyperplasia with a novel CYP21A2 mutation. Intern. Med. J. 46 (9), 1115-1116 (2016). https://doi.org/10.1111/imj.13177

134. H. Falhammar, D.J. Torpy, Congenital adrenal hyperplasia due to 21-hydroxylase deficiency presenting as adrenal incidentaloma: a systematic review and meta-analysis. Endocr. Pract. 22 (6), 736-752 (2016). https://doi.org/10.4158/EP151085.RA

135. H. Falhammar, L. Frisen, C. Norrby, A.L. Hirschberg, C. Almqvist, A. Nordenskjold, A. Nordenstrom, Increased mortality in patients with congenital adrenal hyperplasia due to 21hydroxylase deficiency. J. Clin. Endocrinol. Metab. 99(12), E2715-E2721 (2014). https://doi.org/10.1210/jc.2014-2957

136. A. Nordenskjold, G. Holmdahl, L. Frisen, H. Falhammar, H. Filipsson, M. Thoren, P.O. Janson, K. Hagenfeldt, Type of mutation and surgical procedure affect long-term quality of life for women with congenital adrenal hyperplasia. J. Clin. Endocrinol. Metab. 93(2), 380-386 (2008). https://doi.org/10.1210/jc. 2007-0556.

137. J. Almasri, F. Zaiem, R. Rodriguez-Gutierrez, S.U. Tamhane, A. M. Iqbal, L.J. Prokop, P.W. Speiser, L.S. Baskin, I. Bancos, M. H. Murad, Genital reconstructive surgery in females with congenital adrenal hyperplasia: a systematic review and metaanalysis. J. Clin. Endocrinol. Metab. 103(11), 4089-4096 (2018). https://doi.org/10.1210/jc.2018-01863

138. A.R. Fernandez-Aristi, A.A. Taco-Masias, L. Montesinos-Baca, Case report: Clitoromegaly as a consequence of Congenital Adrenal Hyperplasia. An accurate medical and surgical approach. Urol. Case Rep. 18, 57-59 (2018). https://doi.org/10. 1016/j.eucr.2018.02.011

139. D. MacKay, A. Nordenstrom, H. Falhammar, Bilateral adrenalectomy in congenital adrenal hyperplasia: a systematic review and meta-analysis. J. Clin. Endocrinol. Metab. (2018). https:// doi.org/10.1210/jc.2018-00217 